\title{
THE TUMORAL ETIOLOGY OF THE SUPERIOR CAVA VEIN SYNDROME PRESENTING AS EXSUDATIVE PERICARDITIS IN A YOUNG PATIENT
}

\author{
Mădălina Ioana Moisi ${ }^{1}$, Cosmin Vesa ${ }^{1}$, Larisa Roşan², Vâtcă Liliana², Babeş Katalin¹, \\ Mircea Ioachim Popescu ${ }^{1}$ \\ ${ }^{1}$ University of Oradea, Faculty of Medicine and Pharmacy \\ Emergency County Hospital, Oradea
}

\begin{abstract}
We present the case of a 36-year-old patient admitted with dyspnea, subjective sensation of edema of the cervical region, and precordial pain with sudden onset. Pathological antecedents revealed a respiratory intercourse three weeks ago. Laboratory findings indicated an inflammatory syndrome accompanied by hypoproteinemia. We performed an echocardiographic examination which revealed important pericardial effusion and swinging heart aspect with diastolic collapse of the right atrium and ventricle. According to the existing guidelines pericardiocentesis was immediately required. The hemorrhagic pericardial effusion had an intense positive Rivalta reaction with frequent macrophages and malignant atypical cells. The next step was a full-body computer tomography scan, which revealed an expansive mediastinal mass, invading the upper cava vein and pericardium, with mediastinal adenopathy. A biopsy was performed and the pathology examination concluded there was a classical Hodgkin's lymphoma nodular sclerosis type. Finally the patient was directed to oncology department.
\end{abstract}

Keywords: pericardial effusion, cardiac tamponade, Hodgkin's lymphoma, pericardiocentesis, swinging heart.

\section{Rezumat}

Relatăm cazul unei paciente de 36 de ani care prezintă următoarele acuze: dispnee, senzație subiectivă de edem al regiunii cervicale și durere precordială cu debut brusc. Antecedentele patologice au relevat o intercurenţă respiratorie în urmă cu trei săptămâni. Explorările paraclinice au indicat un sindrom inflamator însoțit de hipoproteinemie. Am efectuat o examinare ecocardiografică care a decelat o importantă colecţie pericardică și aspectul de swinging heart însoţit de colaps diastolic al atriului şi ventriculului drept. Conform ghidurilor din literatura de specialitate, pericardiocenteza a fost indicată de urgenţă. Lichidul pericardic drenat a prezentat un aspect hemoragic cu o reacție Rivalta intens pozitivă și au fost găsite celule macrofage frecvente și celule atipice maligne. 


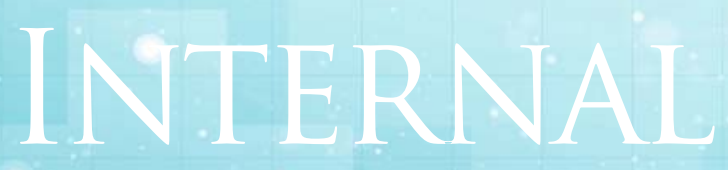

Clinical cases.

Următorul pas a impus relizarea examenului computer tomografic toracic care relevă o masă mediastinală expansivă, invadând vena cavă superioară și pericardul, decelând şi adenopatii mediastinale. A fost efectuată o biopsie pericardică, iar examenul anatomopatologic a concluzionat prezenţa unui limfom Hodgkin clasic de tip scleroză nodulară. În cele din urmă, pacienta a fost îndrumată spre un department oncologic avizat pentru iniţierea tratamentului de specialitate.

Cuvinte cheie: pericardită, tamponadă cardiacă, limfom Hodgkin, pericardiocenteză, swinging heart

\section{Introduction}

Pericardial diseases are relatively common in our clinical practice but the real incidence of them is difficult to appreciate because there are many cases which remain undiagnosed. Men are usually more affected than women. It is mandatory to determinate whether this pathological condition is idiopathic or part of some systemic diseases ${ }^{(1)}$. The main types of pericardial diseases involve infectious or non-infectious causes. Neoplastic pericardial effusion is a concerning problem and it can develop from direct extension or metastatic spread of the underlying malignancy via lymphatics into the pericardium ${ }^{(5)}$. In autopsy series, the prevalence of pericardial involvement varies from $4 \%$ in general autopsies to $15 \%-30 \%$ in autopsies of cancer patients $^{(4)}$.
Pericardial involvement in malignancy is actually a common finding especially in nonHodgkin's lymphoma, breast cancer or pulmonary neoplasia, whilst the primary pericarditis is more rarely revealed.

\section{Case presentation}

A 35 years old non-smoker female was admitted to our department presenting severe dyspnea, subjective sensation of edema in the cervical area, precordial pain accentuated by deep breathing and palpitations with sudden onset, approximatively 3 days ago. Medical history revealed a respiratory intercourse three weeks ago, condition which required antibiotics. At presentation, physical examination outlines the following features: a body temperature of $37.9^{\circ} \mathrm{C}$, the 


\begin{tabular}{|c|c|c|c|}
\hline Material & Analyses & Result & Values \\
\hline \multirow{6}{*}{ Blood } & $\begin{array}{l}\text { Haemocultures - } \\
\text { bacteria }\end{array}$ & Negative & \\
\hline & Haemocultures - fungus & Negative & \\
\hline & RFC Coxiella Burneti & Negative & \\
\hline & $\begin{array}{l}\text { RFC Mycoplasma } \\
\text { pneumoniae }\end{array}$ & Positive & $1 / 640$ \\
\hline & $\begin{array}{l}\text { RFC Leptospira } \\
\text { icterohemoragie }\end{array}$ & Negative & \\
\hline & RFC Leptospira pomona & Negative & \\
\hline \multirow{6}{*}{$\begin{array}{l}\text { Pericardial } \\
\text { effusion }\end{array}$} & Macroscopic & Hemorrhagic & \\
\hline & Culture & Sterile & \\
\hline & Cytology & $\begin{array}{c}\text { Nonspecific inflammation, } \\
\text { malignant cells }\end{array}$ & \\
\hline & Biochemistry & LDH & $816 \mathrm{mg} / \mathrm{dl}$ \\
\hline & & Glucose & $90 \mathrm{mg} / \mathrm{dl}$ \\
\hline & & Proteins & 4.1 \\
\hline \multirow{2}{*}{ Urine } & Culture & Sterile & \\
\hline & Biochemistry & Normal & \\
\hline
\end{tabular}

Table 1. The laboratory findings including blood culture, pericardial liquid examination and urine analysis 
respiratory rate 35/min, low intensity heart sounds; blood pressure was 100/60 $\mathrm{mmHg}$, and heart rate 75 beats per minute.

Electrocardiogram reflected the presence of sinus rhythm with a ventricular rate of $75 /$ min, diffuse negative T wave (Figure 1 ).

We performed a set of global laboratory findings in order to identify more elements for the final diagnosis. There was an inflammatory syndrome certified by increased CRP, erythrocyte sedimentation rate, with normal leucocytes, neutrophil, lymphocytes, TSH, fT4, fT3 and mild hypoproteinemia. We wanted to exclude other sites of infection so we indicated a urine analysis which was normal. Also protein electrophoresis was the next step due to decreased amount of proteins in the blood; the only elements which were mildly raised were the alpha 2 globulins. The blood cultures were negative and those for atypical bacteria demonstrated the presence of Mycoplasma Pneumoniae (Table 1).

Radiographic exam identified the ascension of the right diaphragm with $6 \mathrm{~cm}$, without focal lung injury and enlarged cardiac silhouette (Figure 2). In some cases the classic enlarged cardiac silhouette may not appear in acute tamponade due to the fact that the process requires at least $200 \mathrm{~mL}$ of pericardial fluid ${ }^{(3)}$.

Transthoracic echocardiography revealed reduced ejection fraction $(<35 \%)$ measured by Simpson's rule, pericardial effusion 19 $\mathrm{mm}$ laterally of right ventricle appearing in systole, with swinging heart, collapse of the lateral wall of the right atrium, diastolic collapse of the right ventricle, wave $\mathrm{E}$ decrease by more than $25 \%$ in inspiration and increase in expiration, which is consistent with cardiac tamponade (Figure 3). Pericardiocentesis was quickly demanded and the macroscopic appearance was that of hemorrhagic fluid with atypical malignant cells $^{(1)}$. After the procedure the BP got normal values $(130 / 80 \mathrm{mmHg}$ ) with improving the dyspnea and the initial accuses.

Another element needed was the abdominal echography showing no modification. We requested a more reliable examination such as thoracic CT, an important element for this case management which showed pericardial effusion, an expansive mass in the anterior mediastina which was compressing the superior cava vein and aortic adenopathy, reflecting the suspicion of lymphoma (Figure 4). The abdominal CT didn't reveal notable elements.

Thoracic surgeons were the ones who succeeded to obtain some biopsies from the pericardial layer through a mini-thoracotomy. Considering the invasion of the mediastinal formation in the pericardium and upper cava vein, without the possibility of pericardiotomy or fenestration, the best solution was to perform a ultrasound guided pericardial 


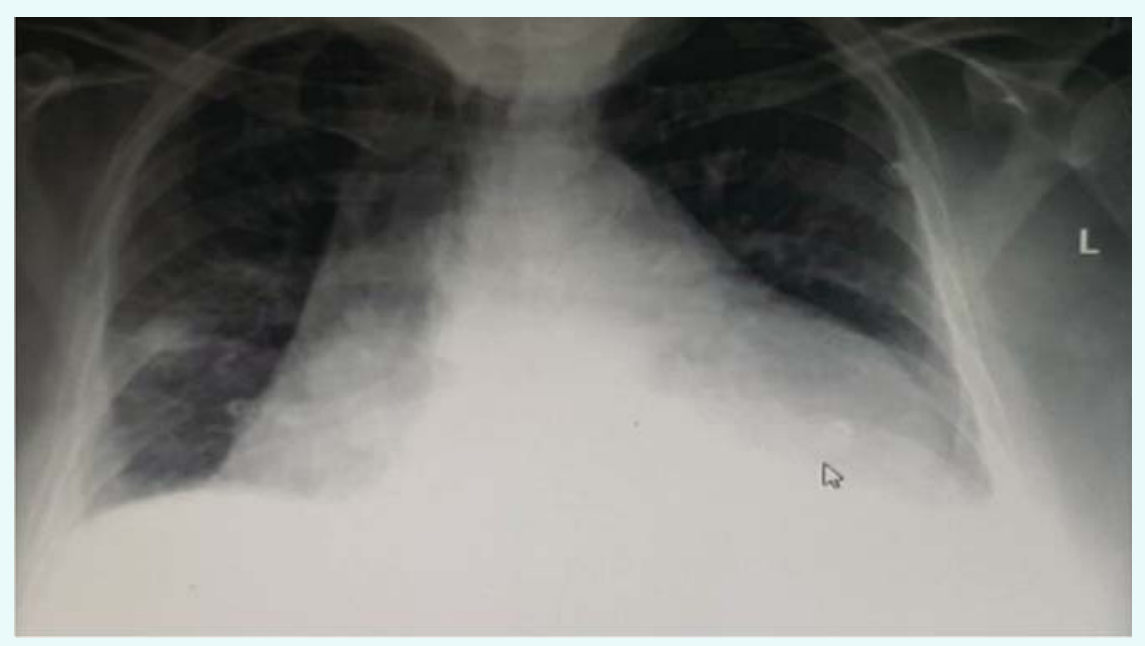

Figure 2. The chest $X$ ray showing an enlargement of the cardiac silhouette

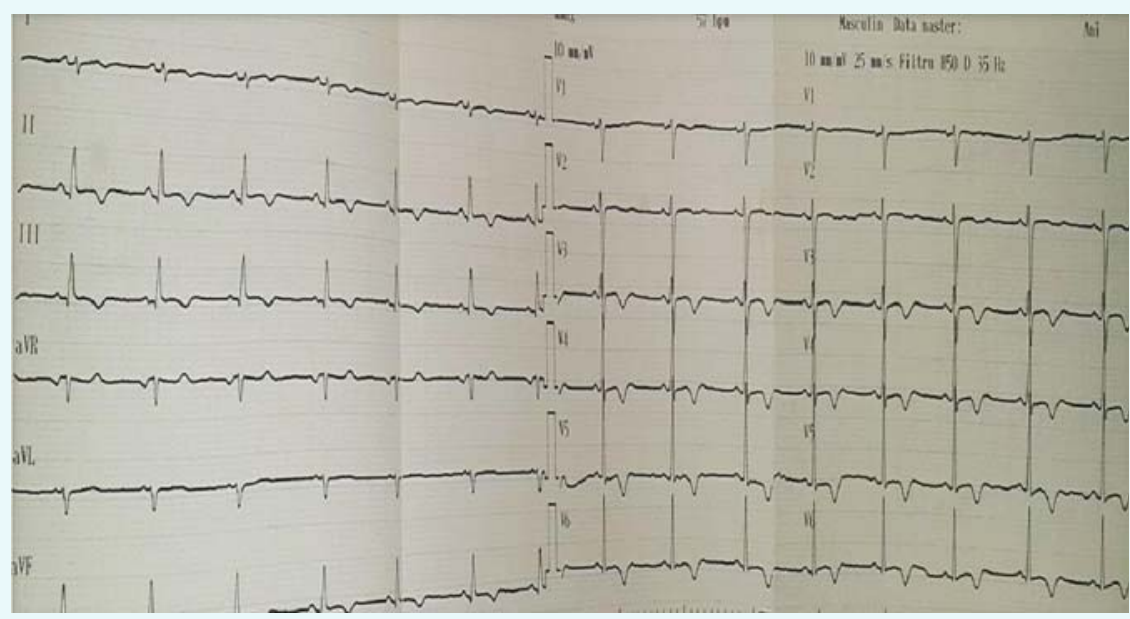

Figure 3. ECG showing sinusal rhytm, 75 beats/min, diffuse negative $T$ wave in inferior and anter-septal limbs
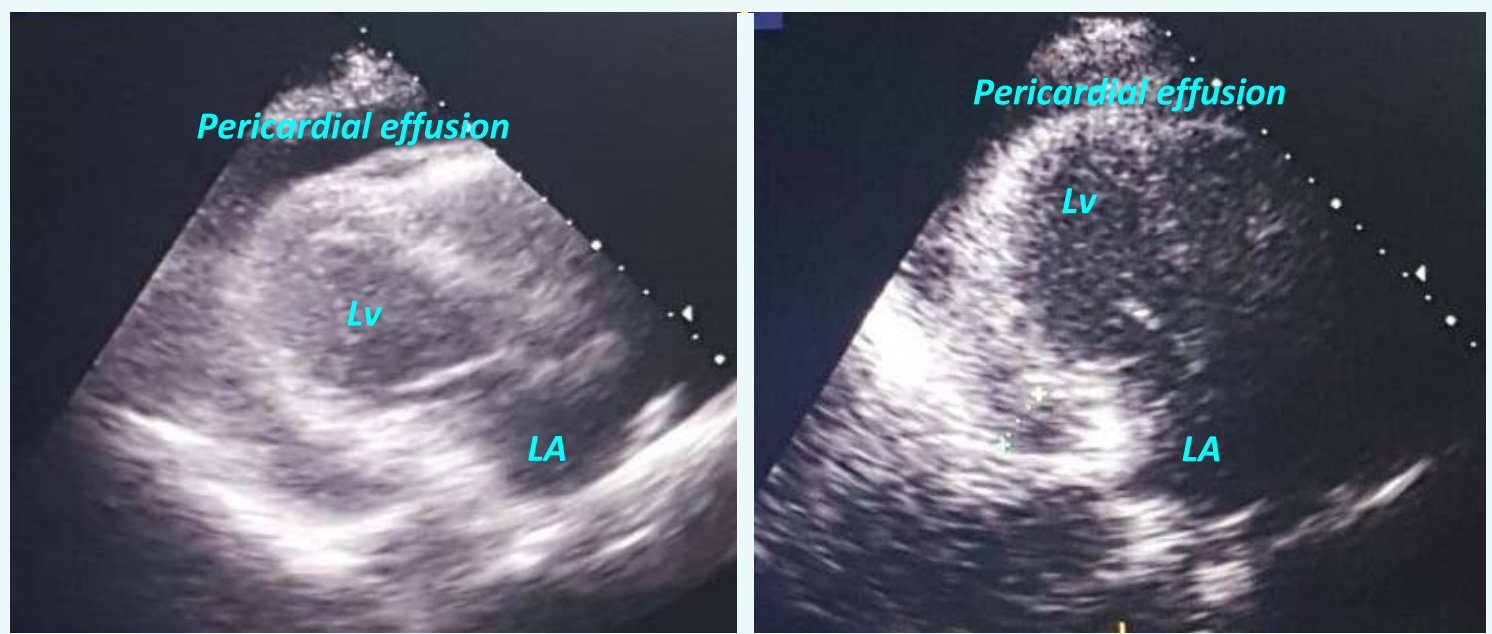

Figure 3. TTE - Apical 4 chambers view - the pericardial effusion is illustrated as well as the diastolic collapse of the right ventricle 


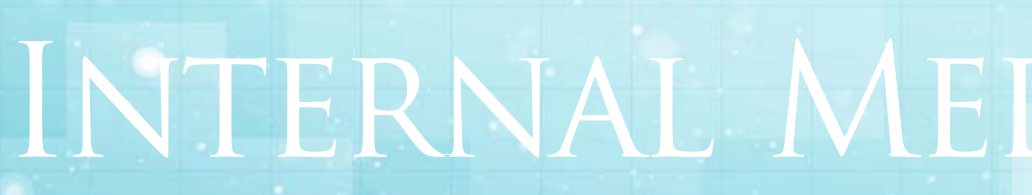

Clinical cases

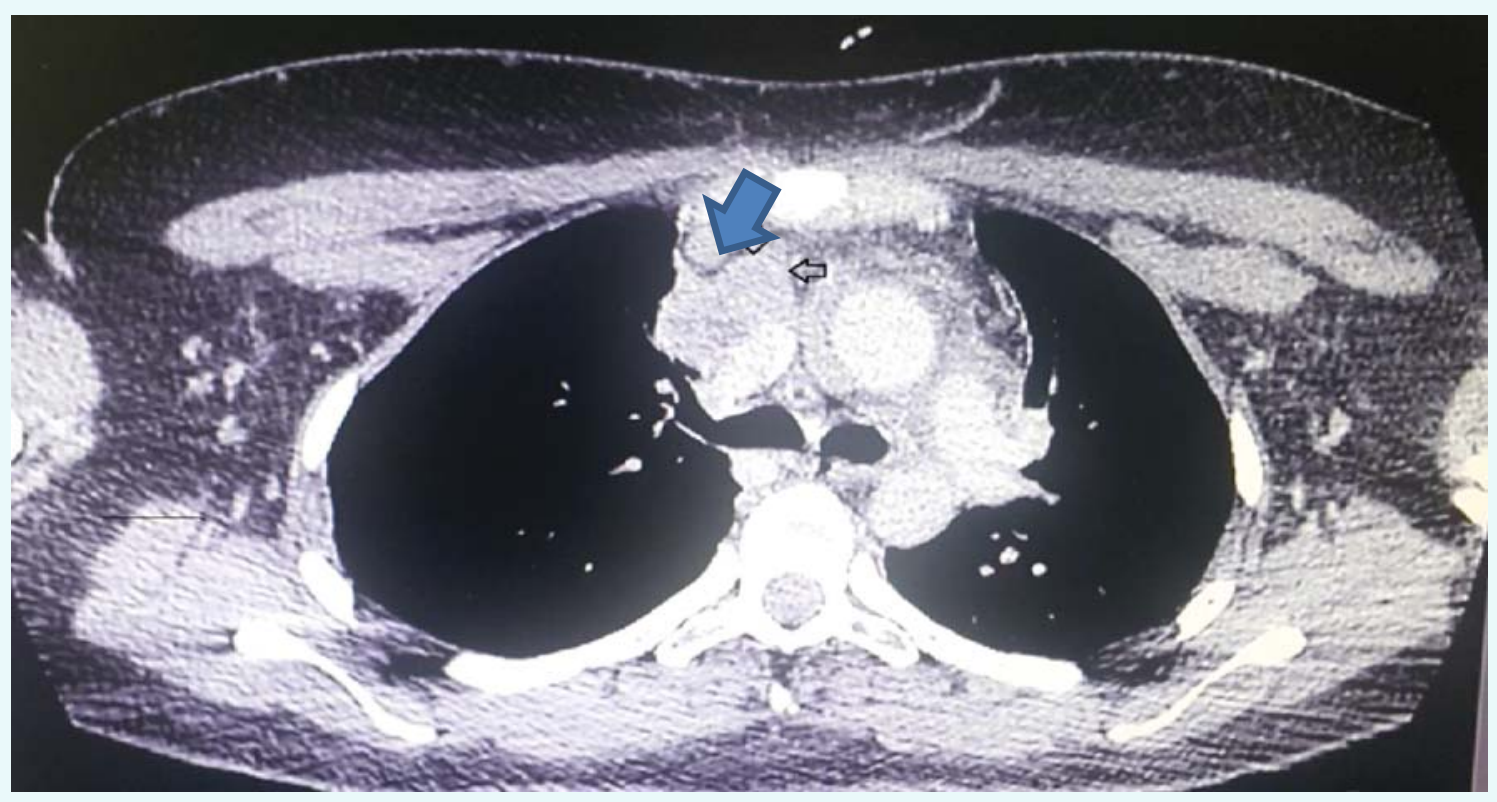

Figure 4 . Axial thoracic CT examination revealing a mediastinal mass invading the upper cava vein (arrows)

drainage using a catheter of $7 \mathrm{Ch}^{(4)}$. The results of these maneuvers have materialized in the considerable improvement of dyspnea and the inflammatory markers showed a declining trend.

The pathological exam gave the final verdict: classical Hodgkin's lymphoma- nodular sclerosis type, describing tumor cells with nuclear atypia and intratumor necrosis. Reed Sternberg cells positive to CD15 and CD30 markers were also discovered. The patient was directed to oncology department in order to find the best therapeutic option for this disease.

\section{Discussions}

Neoplastic etiology of the pericardial effusion is a common finding in some malignancies but there are a few cases of HL discovered due to the cardiac tamponade manifestation. Only $5 \%$ of the patients with $\mathrm{HL}$ have associated pericarditis ${ }^{(6)}$.

Moreover non-Hodgkin's lymphoma is rarely responsible for the pericardial involvement. The incidence of pericarditis was evaluated in a systematic review gathering 1600 patients with leukemia where the follow up 
included periodically echocardiography examination. The analysis of this retrospective study reveals that 325 patients (20\%) had pericarditis, most of the reported cases showed mild pericardial effusion, only $3 \%$ required drainage of the pericardial fluid $^{(7)}$.

Pericardial diseases are difficult to detect in hemodynamically stable patients with normal physical examination, the only element that could raise the suspicion of a pericardial effusion is the unexplained tachycardia ${ }^{(6)}$. In the presented case the medical history describing a recent infection could have given the fake impression that the substrate was an infectious pericarditis. Usually the neoplastic pericarditis is asymptomatic.

The cardiac tamponade represents a medical emergency and requires immediate medical interventions that can improve the patient condition. This is the result of the pericardial liquid pressure that overcomes the cardiac filling pressure causing an improper filling of the ventricle with drastically drop in the cardiac output. Pericardiocentesis is the immediate solution.

The mechanisms leading to pericarditis in malignancies are various. There can be a metastasis of the tumoral cells via the lymphatic or hematogenous circulation ${ }^{(8)}$. Affecting the circuit of the pericardial fluid by diminishing the amount of liquid which is reabsorbed in the venous and lymphatic vessels may represent another hypothesis. Finally the mediastinal large adenopathy can impair the lymphatic drainage of the pericardial fluid without invasion of the pericardium layer $^{(9)}$.

The major problem concerning this pathology is the high recurrence rate. A pleuropericardial window or intrapericardial infusion of the antineoplastic agent and pericardiectomy may represent important elements for the treatment of pericardial neoplasia. Usually in lymphomas systemic chemotherapy is suitable due to the fact that the most important mechanism of metastasis is the hematogenous pathway. Other solid tumors like lung cancer require both local and systemic chemotherapy ${ }^{(10)}$.

The particularity of this case relies in:

- the initial presentation of the underlying $\mathrm{HL}$ as an exudative pericarditis complicated with cardiac tamponade in a young patient without medical history.

- the fact that the initial suspicion based on a recent respiratory infection may have mislead the diagnostic algorithm and the treatment if there wasn't the clinical suspicion of another underlying cause of the massive hemorrhagic pericardial effusion.

- the normal values for the BP and the immediate relief of symptoms were obtained after the drainage of the large pericardial effusion.

\section{Conclusions}

The best therapeutic choice for treating pericardial diseases requires the proper identification of the major cause responsible for the disease. Even if the given information leads to a final conclusion we should always consider the patient's symptoms. Occasionally, the initial clinical evaluation reveals a distinct finding that fits into a more circumscribed problem ${ }^{(4)}$.Cardiac tamponade presence and the hemorrhagic aspect of pericardial effusion are the major findings that abolished the initial presumption of infectious pericarditis ${ }^{(2)}$. All the possible locations that may constitute the starting 


\section{INTERNAL}

\section{Clinical cases}

point for an infectious pericarditis must be ruled out. There are some cases of large pericardial effusion without an obvious cause following routine evaluation and they suggest the presence of an malignant process $^{(3)}$. Malignant causes of pericardial disease represent a rare condition in young people, but this fact shouldn't stop us from eliminating the possibility when we are trying to find out the causes of the diseases. We should consult the guidelines and corroborate the data with our clinical judgement in order to find the successful approach for our patients.

The authors declare that there are not conflicts of interest.

\section{References}

1. Imazio M., Gaita F., Lewinter M., Evaluation and Treatment of Pericarditis A Systematic Review. JAMA 2015; 314(14): 1498-1506.

2. Adler Y, Charron P, Imazio M, et al. ESC Guidelines for the diagnosis and management of pericardial diseases, The Task Force for the Diagnosis and Management of Pericardial Diseases of the European Society of Cardiology (ESC). Eur Heart J. 2015; 36: 2921-2964.

3. Jatinder M., Mokta K., et al. A swinging heart. Indian J Endocrinol Metab 2013; 17: 660-661.

4. Waqas J, Osman $M$, Electrical Alternans with Pericardial Tamponade, N EnglJ Med 2015; 373: e10.

5. Mary $P$, Management of Malignant Pericardial Effusion, JAdv Pract Oncol 2014; 5:281-289.

6. Marwan R, William K, Neoplastic Pericardial Effusion, Clin. Cardiol. 2011; 34, 10: 593-598.

7. Sampat K, Rossi A, Garcia-Gutierrez V, Cortes J, Pierce S, Kantarjian H, Garcia-Manero G. Characteristics of pericardial effusions in patients with leukemia. Cancer 2010; 116: 2366-2371.

8. Soman B, Vijayaraghavan G, Pericardial involvement in neoplastic disease: prevalence, clinical picture, diagnosis and treatment, E-Journal of Cardiology Practice, 13 Dec 2017, Vol. 15, No. 25.

9. Hajra A, Bandyopadhyay D, Mukhopadhyay S, Cardiac Tamponade as Initial Presentation of Hodgkin Lymphoma, Journal of Clinical Imaging Science. 2015;5:67.

10. Lestuzzi C. Neoplastic pericardial disease: Old and current strategies for diagnosis and management, World J Cardiol 2010 September 26; 2(9): 270-279. 